\title{
Validating the Language Mindsets Inventory
}

\section{Paul Collett}

\section{Shimonoseki City University}

\section{Michael Berg \\ University of Liverpool}

\section{Reference Data:}

Collett, P., \& Berg, M. (2020). Validating the Language Mindsets Inventory. In P. Clements, A. Krause, \& R. Gentry (Eds.), Teacher efficacy, learner agency. Tokyo: JALT.

https://doi.org/10.37546/JALTPCP2019-22

In this study, the authors adopted Lou and Noels's $(2016,2017)$ Language Mindset Inventory. This was administered to students $(N=825)$ at 2 universities in southwestern Japan. Factor analysis revealed a 4-factor model, as opposed to the 3- and 6-factor models found by Lou and Noels, suggesting a limited fit within a Japanese EFL context. Regression analysis was used to compare students' mindsets with their EFL proficiency, revealing a small effect size but positive correlations with growth mindsets and no correlation with fixed mindsets, suggesting that whether students subscribe to growth or fixed mindsets does play a part in proficiency, however, a limited one. Further implications are discussed.

本研究では、Lou and Noels (2016, 2017)のLanguage Mindset Inventoryを採用した。これは、学生の (growth/fixed=成 長型の・固定型の) mindsets (考え方) を明らかにする診断ツールである。調査は、西南日本の2つの大学の学生 $(N=825)$ を 対象に実施された。因子分析では、Lou and Noels $(2016,2017)$ の3因子および6因子モデルとは対照的に、4因子モデルが明 らかになつた。回帰分析では、学生のmindsetsとEFLの習熟度を比較し、効果量は少ないがgrowth mindsetsとの正の相関関 係を明らかにし fixed mindsetsとの相関関係がないことを示し、英語の習熟には、学生が成長型の考え方 (growth mindsets) をするか、または固定型の考え方 (fixed mindsets)をするかが、限定的ではあるが、関与していることを示唆する。さらなる分 析の含意についても議論する。 indsets (or self-theories of intelligence) are the beliefs we hold about our intellectual capabilities. The idea of mindsets arose from the work of the psychologist Carol Dweck and colleagues (Dweck, 2006; Lou \& Noels, 2019). Their findings showed that people ascribe general understandings of intellectual ability to one of two contrasting theories, and the theory endorsed can have a significant influence on academic performance and wider aspects of cognitive functionality. An entity, or fixed mindset, holds that people are born with a certain level of ability and are basically unable to move beyond this level through study or practice. Contrasting this is the incremental, or growth, mindset: the idea that ability is mutable and that one can become smarter or more adept at something through appropriate study and practice.

The mindsets that people hold are seen as important determinants for learner motivation. Those who hold fixed mindsets are characterised as conceptualising failure in an endeavour as an indication of low intelligence or a lack of ability. Rather than engaging in activities that they perceive as difficult and could lead to failure, which would imply a lack of ability on their behalf, they will disengage from the activities and instead focus on accounting for negative outcomes as a consequence of factors outside their control. People who hold growth mindsets see failure as a result of a lack of effort, poor strategy use, or inappropriate goals. In other words, it is due to a problem with their approach to learning. By using prior outcomes as a guide, they can try new approaches and ideally move forward. A simple conceptualisation of the difference between the two mindsets is the fixed idea of I can't do it as against the growth idea of I can't do it-yet.

Although yet to be explored in much depth within the foreign-language learning field, the existing research into mindsets offers insights into why some language learners perform better than others, with mindsets being identified as an important factor in language learner agency (Ryan \& Mercer 2011, 2012). Lou and Noels $(2016,2017)$ posited the idea of language mindsets: "domain specific beliefs about whether the ability to learn languages is malleable or not" (Lou \& Noels, 2019, p. 2). They created an instrument to use in measuring these mindsets: the Language Mindsets Inventory (LMI), an 18-item 
scale that measures dimensions of learner beliefs identified as underlying the mindset construct. This paper details findings from a survey that incorporates a Japaneselanguage version of the LMI. Results of a factor analysis of the Japanese version of the LMI (here referred to as J-LMI) are discussed in light of Lou and Noels' findings as well as a selection of some of the broader findings uncovered by the survey as a whole.

\section{Background}

Current theory on mindsets suggests that people hold a mixture of fixed and growth mindsets. They are also seen as context dependent: Someone could hold a growth mindset about one aspect of ability whilst subscribing to fixed mindsets in other domains (Lou \& Noels, 2019). Importantly, mindsets can also be changed via appropriate interventions. Said interventions often comprise little more than explicitly explaining to students-in essence convincing them - that their ability or intelligence is not static and, with the right amount of effort, can be improved. For example, Good, Aronson, and Inzlicht (2003) conducted two 90-minute growth mindset mentoring sessions in a test group of seventh-grade math students in a rural school district in the United States, leading to a 4.5-point increase in math scores. At the tertiary level, Yeager et al (2016) worked on changing the mindsets of disadvantaged students enrolled in and transitioning to university within a total of 69 high schools in the United States and Canada, reducing the achievement gap by $31 \%$ to $40 \%$. Aronson, Fried, and Good (2002) conducted similar interventions in the United States, resulting in gains for all students. What is shown consistently is that in almost any scholastic realm in which students face challenges, there are students struggling due to what may in part be remediable psychological barriers, and this is borne out in the literature (Blackwell, Trzesniewski, \& Dweck, 2007; Dweck, 2000, 2006, 2008; Elliot \& Dweck, 2013; Spenner, 2017).

It should be noted that the longevity of these interventions is still up for debate, and as with the research outlined above, most studies here have been carried out in North American settings. Dweck (2006) found intervention results to be resilient 2 years following an intervention; Schmidt, Shumow, and Kackar-Cam (2017) found a steady upward grade trajectory via multiple interventions with students in Grades 7 to 9; Aronson et al. (2002) found the effects of a single intervention still held after one year. Other studies have shown the impact of interventions to be more short-lived (Meyers, van Woerkom, de Reuver, Bakk, \& Oberski, 2015; Rattan, Good, \& Dweck, 2012). Unsurprisingly, a single intervention produces different results than repeated interventions, and intuitively one can assume the length and intensity as well as teacher support for the interventions would also factor in.
Research into mindsets for foreign or second language learning is still relatively underdeveloped, so it is unclear how the results outlined above may translate into this area. One issue that has perhaps held back research into mindsets for language learning has been the lack of a suitable instrument to measure them. Here, the development of the LMI appears to be a promising step.

\section{The Language Mindset Inventory}

Lou and Noels $(2016,2017)$ developed the LMI as a scale to measure the mindsets of language learners. This 18 -item scale has three subscales that they postulated as representing a fixed and growth mindset dimension measuring age-sensitive beliefs about learning (ASB), general language intelligence beliefs (GLB), and second language aptitude beliefs (L2B). See the Appendix for the scale items. The scale was developed with a sample of 1,633 second-language learners attending Canadian universities. Through confirmatory factor analysis (CFA), Lou and Noels found three models that best fit the data:

a 2-factor model with entity and incremental beliefs loading on two separate factors;

- a 3-factor model representing GLB, L2B, and ASB; and

- a 6-factor model representing incremental and entity beliefs for each of the three aspects.

They suggested that the LMI could be used based on any of these models depending on the particular interests or aims of a researcher.

The question we wished to answer was whether it would be possible to replicate these findings in a Japanese EFL context. Uncovering a similar factor structure based on our data, namely responses to a survey incorporating a Japanese-language version of the LMI, would help validate the utility of the instrument as a tool to measure language mindsets. Understanding the nature of how mindsets comprise part of the challenges Japanese EFL learners face is a fruitful avenue of investigation, particularly when said challenges are potentially remediable. How, then, did this initial analysis of the J-LMI compare to the original version?

\section{Method}

The survey used in this study consisted of three sections: (a) a first section of demographic questions, (b) Lou and Noels's $(2016,2017)$ aforementioned 18-item 
mindset battery, and (c) a final section that looked to assess students' EFL proficiency. Here, students were also asked to give their TOEIC test scores if available and if they could remember them and asked questions about their own proficiency via a 7-item selfrated language proficiency (SRP) section. This consisted of a 7-point Likert scale in which students ranked their vocabulary, grammar, reading, writing, speaking, listening, and overall English ability in comparison to their peers. The SRP score was simply an average of these seven metrics fixing each student with a number from 1 to 10 .

The survey was set up using Google Forms, with the original LMI scale items translated into Japanese, back-translated, and then piloted with 20 students for accuracy. The Japanese versions of the LMI questions are listed in the Appendix. Once finalised, the link to the questionnaire was distributed to foreign language teachers at two different universities in southwestern Japan, requesting them to ask students in their English classes to complete the online questionnaire. Students were free to answer the questions in class, or in their own time, with the survey generally taking less than 10 minutes to complete. All questions and responses were in Japanese. Names were not collected, but respondents were asked to provide optional contact details if they were interested in doing a follow-up interview regarding their responses. Students were informed in the survey preamble that the survey was voluntary and that completing it comprised consent to use their responses for research purposes. Institutional consent was granted in writing at both universities by the appropriate department heads. Eight hundred twenty-five useable responses were collected from students in a variety of departments, including English and non-English majors.

Once the data had been collated, exploratory factor analysis (EFA) was used to reveal the patterns in responses to the 18 scale items on the J-LMI. EFA was favoured over CFA for a number of reasons. Both methods are used to generate models or theories based on empirical data collected in research. However, CFA is often used in a deductive manner, fitting the data to a model based on existing theory; as such, its use is usually recommended when there is a strong theoretical background to account for the expected factor structure, along with existing empirical evidence to support this (Brown, 2016; Finch, 2019). EFA is more of an inductive tool; it is used to generate factors that can account for patterns in data as an initial stage in model creation or theory generation. In this respect, as Lou and Noels (2017) pointed out, there is little research into mindsets in the foreign- or second-language learning field, so it is unclear if any particular theoretical perspective could be fitted to a model to represent the data. Furthermore, creating a translated version of an existing survey is akin to creating a new version of the survey, and it is probably not appropriate to assume the same assumptions fit about the recipients' understanding of the questions as in the original English version of the survey. Advice given here is that "a reevaluation of the factor structure of a test [is called for] when a test is translated to a different language" (Flora \& Flake, 2017, p. 83).

The factor analysis was performed with the psych package (Revelle, 2019) in the R Project for Statistical Computing (Version 1.9.12). A linear regression of the respondents' TOEIC test results and their SRP scores with their mindset scale responses was also performed to help provide a basic measure of validity for the scale.

Results

\section{Factor Analysis}

The analysis used a polychoric correlation matrix with oblique factor rotation (oblimin) and maximum likelihood estimation. Polychoric correlation is recommended in cases where the data is ordinal in nature, as is the case with the scale used in this study. An oblique factor rotation approach was determined to be most appropriate as this assumes correlation between the factors (Field, Miles, \& Field, 2012; Finch, 2019).

Before carrying out the EFA, the correlation matrix was checked to ensure it met necessary assumptions. Bartlett's test of sphericity indicated that the correlations between scale items were of an appropriate level for the factor analysis. The overall $\mathrm{KMO}$ measure, which checks if the sample size is adequate for factor analysis, was .9, considered "great" under Kaiser's (1974) original conceptualisation. All individual KMO measures were above .78. The determinant of the correlation matrix $(0.00013)$ indicated there was no problem with multicollinearity (a high degree of correlation between variables)

To decide on the number of factors, parallel analysis and Very Simple Structure (VSS; Revelle, 2019) were used. The best fit here was for a 2-factor solution. although the parallel analysis also suggested a 4-factor solution. As Lou and Noels (2017) suggested, a 2-factor solution was appropriate with their version of the LMI; this was first tested. The factor loadings after rotation are presented in Table 1 with a corresponding factor path diagram in Figure 1. The test of the hypothesis that two factors are sufficient had $\chi^{2}(118)=1158.43, N=825$, with goodness of fit indices Tucker Lewis Index of factoring reliability $(\mathrm{TLI})=0.81$, RMSEA $=.104,90 \%$ CIs $[.098, .109]$, SRMR $=.056$, and BIC $=366.02$. It is clear that the survey items load on two separate factors; this matches the 2-factor model of the English-language LMI, with one factor (ML1 in Figure 1) representing an incremental or fixed mindset measure and the other (ML2) an entity or growth mindset dimension. 
Table 1. Factor Loadings for 2-Factor Solution

\begin{tabular}{lcc}
\hline Item & \multicolumn{2}{c}{ Oblimin rotated factor loadings } \\
\cline { 2 - 3 } & Growth mindsets & Fixed mindsets \\
\hline GLBe1 & .00 & .43 \\
L2Bi1 & .72 & .15 \\
ASBe1 & .03 & .63 \\
L2Be1 & .03 & .51 \\
GLBi3 & .71 & -.07 \\
ASBi1 & .78 & -.03 \\
L2Be2 & .36 & .56 \\
GLBe2 & -.08 & .65 \\
ASBe2 & -.20 & .65 \\
GLBi1 & .66 & -.11 \\
L2Bi2 & .88 & .07 \\
ASBi2 & .82 & -.01 \\
GLBe3 & -.20 & .58 \\
L2Be3 & -.16 & .44 \\
ASBe3 & .17 & .48 \\
L2Bi3 & .73 & -.08 \\
GLBi2 & .66 & -.06 \\
ASBi3 & .72 & -.10 \\
\hline Eigenvalues & 5.34 & 2.90 \\
\% of variance & 29.68 & 16.09 \\
$\alpha$ & .77 & .90 \\
\hline
\end{tabular}

Note. Factor loadings > .30 are in bold text.

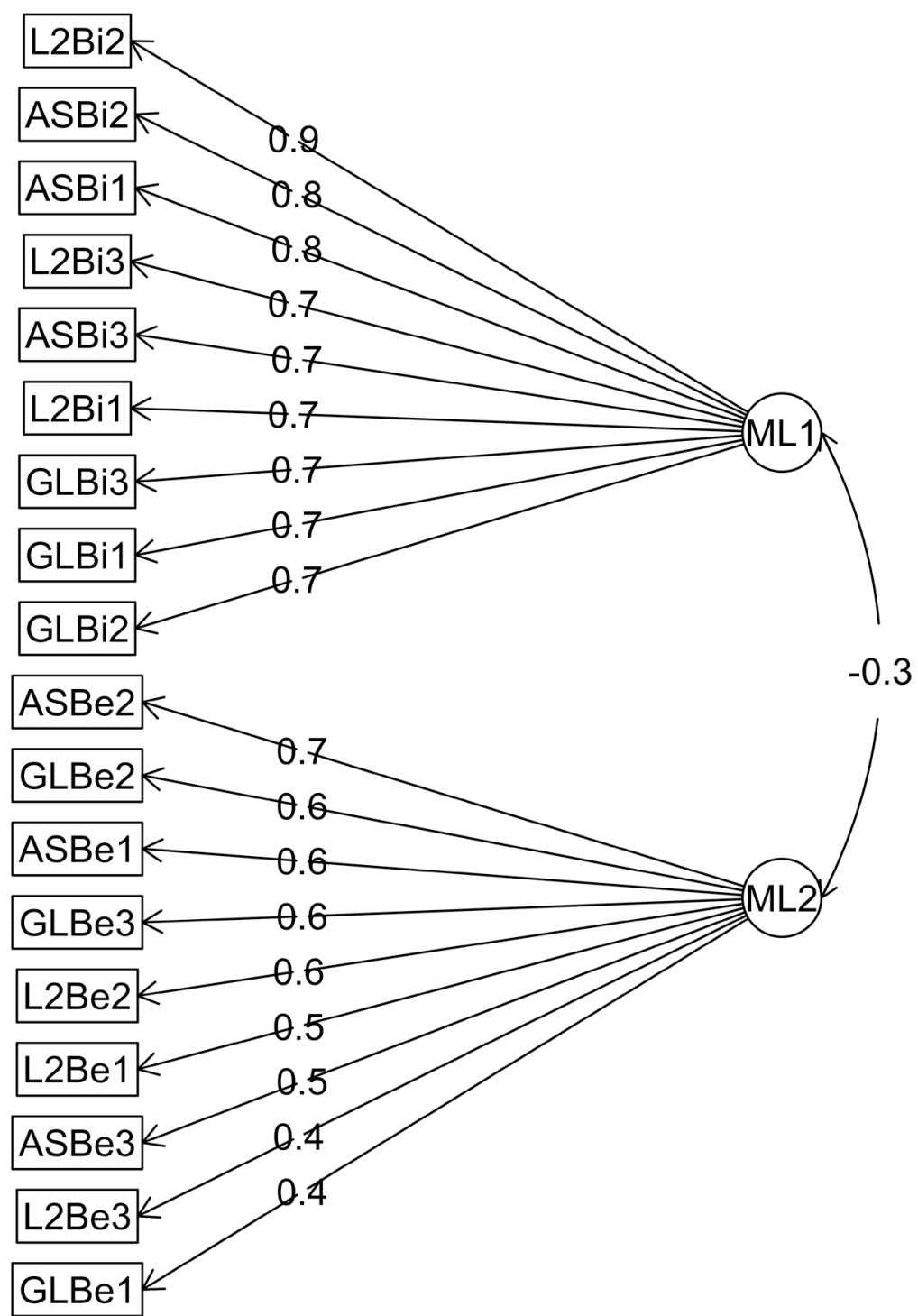

Figure 1. Factor loadings for 2-factor solution. ML1 represents growth mindset scale items; ML2 consists of fixed mindset scale items. 
Table 2. Factor Loadings for 4-Factor Solution

\begin{tabular}{|c|c|c|c|c|}
\hline \multirow{2}{*}{ Item } & \multicolumn{4}{|c|}{ Oblimin rotated factor loadings } \\
\hline & $\begin{array}{c}\text { Potential via } \\
\text { hard work }\end{array}$ & $\begin{array}{c}\text { Innate } \\
\text { hinderances }\end{array}$ & $\begin{array}{l}\text { Universal } \\
\text { potential }\end{array}$ & $\begin{array}{l}\text { Age-related } \\
\text { hinderances }\end{array}$ \\
\hline GLBe1 & .07 & .56 & .02 & -.02 \\
\hline L2Bi1 & .59 & -.14 & .08 & .20 \\
\hline ASBe1 & -.07 & .02 & .01 & .78 \\
\hline $\mathrm{L} 2 \mathrm{Be} 1$ & .14 & .38 & -.10 & .21 \\
\hline GLBi3 & .27 & -.29 & .44 & .18 \\
\hline ASBi1 & .70 & -.10 & .08 & -.03 \\
\hline $\mathrm{L} 2 \mathrm{Be} 2$ & .43 & .11 & -.14 & .48 \\
\hline GLBe2 & .14 & .60 & -.18 & .16 \\
\hline $\mathrm{ASBe} 2$ & -.26 & .28 & .03 & .55 \\
\hline GLBi1 & .22 & -.10 & .51 & -.01 \\
\hline $\mathrm{L} 2 \mathrm{Bi} 2$ & .77 & -.06 & .11 & .04 \\
\hline ASBi2 & .78 & .03 & .09 & -.14 \\
\hline GLBe3 & -.04 & .72 & -.06 & .05 \\
\hline $\mathrm{L} 2 \mathrm{Be} 3$ & -.18 & .64 & .15 & -.02 \\
\hline ASBe3 & .10 & .20 & .05 & .36 \\
\hline $\mathrm{L} 2 \mathrm{Bi} 3$ & .13 & .03 & .77 & -.05 \\
\hline GLBi2 & -.02 & .00 & .84 & .03 \\
\hline ASBi3 & .55 & .08 & .27 & -.24 \\
\hline Eigenvalues & 3.31 & 2.29 & 2.44 & 1.67 \\
\hline$\%$ of variance & 18.37 & 12.73 & 13.58 & 92.79 \\
\hline$\alpha$ & .86 & .72 & .83 & .66 \\
\hline
\end{tabular}

Note. Factor loadings $>.30$ are in bold text.

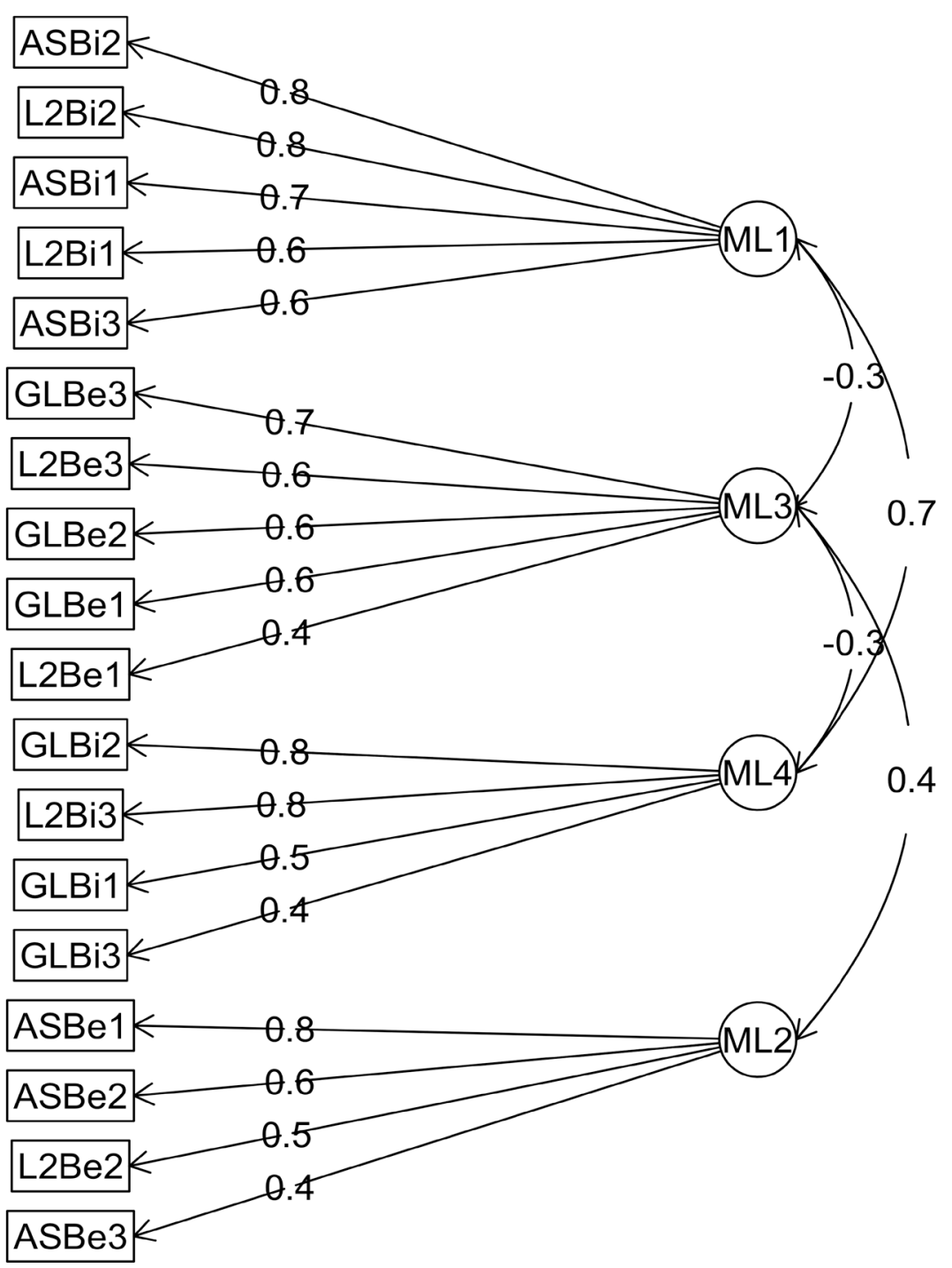

Figure 2. Factor loadings for 4-factor solution. ML1 and ML4 represent growth mindset scale items; ML2 and ML3 consist of fixed mindset scale items. 
Following recommendations given in Brown (2016) and Preacher and MacCallum (2003), a number of preliminary oblique factor rotation approaches were applied to the data to see which gave the best solution. We were unable to fit a 3- or 6- factor model to our data, however, with the most suitable solution being a 4 -factor model using oblimin rotation; this gave the most appropriate fit based on the criteria outlined by
Kline and Thurstone for very simple structure (Brown, 2016). The test of the hypothesis that four factors are sufficient gave $\chi^{2}(87)=422.75, N=825$, with goodness of fit indices $\mathrm{TLI}=.917, \mathrm{RMSEA}=.069,90 \% \mathrm{Cls}[.062, .075], \mathrm{SRMR}=.027$, and $\mathrm{BIC}=-161.49$. The final model consisted of two factors comprising growth mindset items and two factors comprising fixed mindset items (Figure 2). The factor loadings and other statistics are

Table 3. Regression Results of TOEIC Scores With Growth and Fixed Mindset Scales

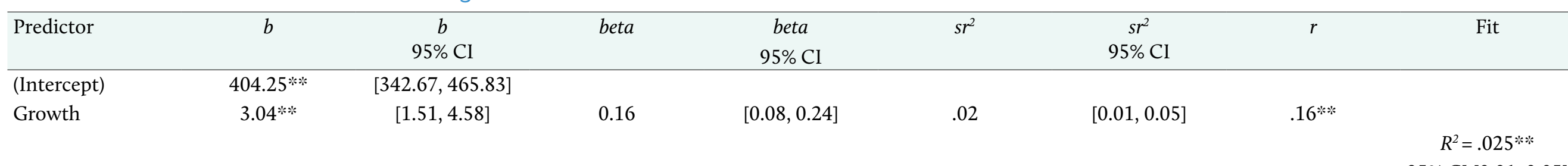

$\begin{array}{lcc}\text { (Intercept) } & 565.13 * * & {[508.80,621.46]} \\ \text { Fixed } & -1.38 & {[-3.21,0.46]}\end{array}$

$-0.06 \quad[-0.14,0.02]$

.00

$[0.00,0.02]$

$-.06$

$95 \% \mathrm{CI}[0.01,0.05]$

$R^{2}=.004$

$95 \% \mathrm{Cl}[0.00, .002]$

Table 4. Regression Results of SRP Scores With Growth and Fixed Mindset Scales

\begin{tabular}{|c|c|c|c|c|c|c|c|c|}
\hline Predictor & $b$ & $\begin{array}{c}b \\
95 \% \mathrm{CI}\end{array}$ & beta & $\begin{array}{c}\text { beta } \\
95 \% \mathrm{CI}\end{array}$ & $s r^{2}$ & $\begin{array}{c}s r^{2} \\
95 \% \mathrm{Cl}\end{array}$ & $r$ & $\begin{array}{c}\text { Fit } \\
95 \% \mathrm{Cl}\end{array}$ \\
\hline (Intercept) & $3.33 * *$ & {$[2.84,3.83]$} & & & & & & \\
\hline Growth & $0.03 * *$ & {$[0.02,0.05]$} & 0.18 & {$[0.11,0.25]$} & .03 & {$[0.01,0.06]$} & $.18 * *$ & $\begin{array}{l}R^{2}=.033 * * \\
{[0.01,0.06]}\end{array}$ \\
\hline (Intercept) & $4.79 * *$ & {$[4.32,5.25]$} & & & & & & \\
\hline Fixed & 0.00 & {$[-0.02,0.01]$} & -0.02 & {$[-0.09,0.05]$} & .00 & {$[0.00,0.01]$} & -.02 & \\
\hline
\end{tabular}

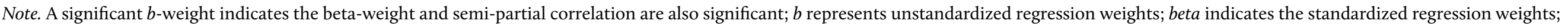
$s r^{2}$ represents the semipartial correlation squared; $r$ represents the zero-order correlation. $\mathrm{Cl}=$ confidence interval.

$* p<.05$. ** $p<.01$. 
presented in Table 2 . This 4 -factor model had similar reliability ratings to the original LMI scale though considerably weaker correlations between factors.

\section{Regression Analysis}

A regression analysis was used to test the results of the 2-factor LMI against student TOEIC scores and their SRP measures; these two measures had a correlation of $r=.47$. Statistically significant results were found for the regression of growth mindsets with TOEIC scores, $F(1,596)=15.16, p<.01$ and for SRP scores, $F(1,823)=27.80, p<.00$. Full results are presented in Tables 3 and 4 , with corresponding scatterplots in Figures 3 to 6 . The regression results show a positive linear increase in both TOEIC scores and SRP with a corresponding increase in growth mindset scores on the I-LMI but a decrease in TOEIC scores and SRP as fixed mindset scores increase. However, in all cases the effect sizes are small

\section{Discussion}

Although the data supported a 2-factor model matching that of the original LMI, the goodness of fit indices are somewhat weak, based on the guidelines provided by $\mathrm{Hu}$ and Bentler (1999). It should also be noted there is complexity in the model, with the L2Be2 variable having relatively high loadings on both factors. This variable has complex loadings in the 4-factor model, with relatively high loadings across other factors also apparent. Removing L2Be2 from the analysis did not result in a better fit, and as it was part of the original study, it was decided to leave it in for this analysis.

The main difference with the original LMI scale is the inability to fit a 3- or 6-factor model to our data. Given this difference, the factors in the J-LMI need to be reconceptualised to fit a 4 -factor model (Figure 2). The two growth-scale item factors appear to represent achievement potential via hard work (ML1) and general change potential (ML4). In the case of the two factors on which the fixed-scale items have the highest loadings, the factors can perhaps best be perceived as innate hinderances (ML3) and agerelated hinderances $(\mathrm{ML} 2)$.

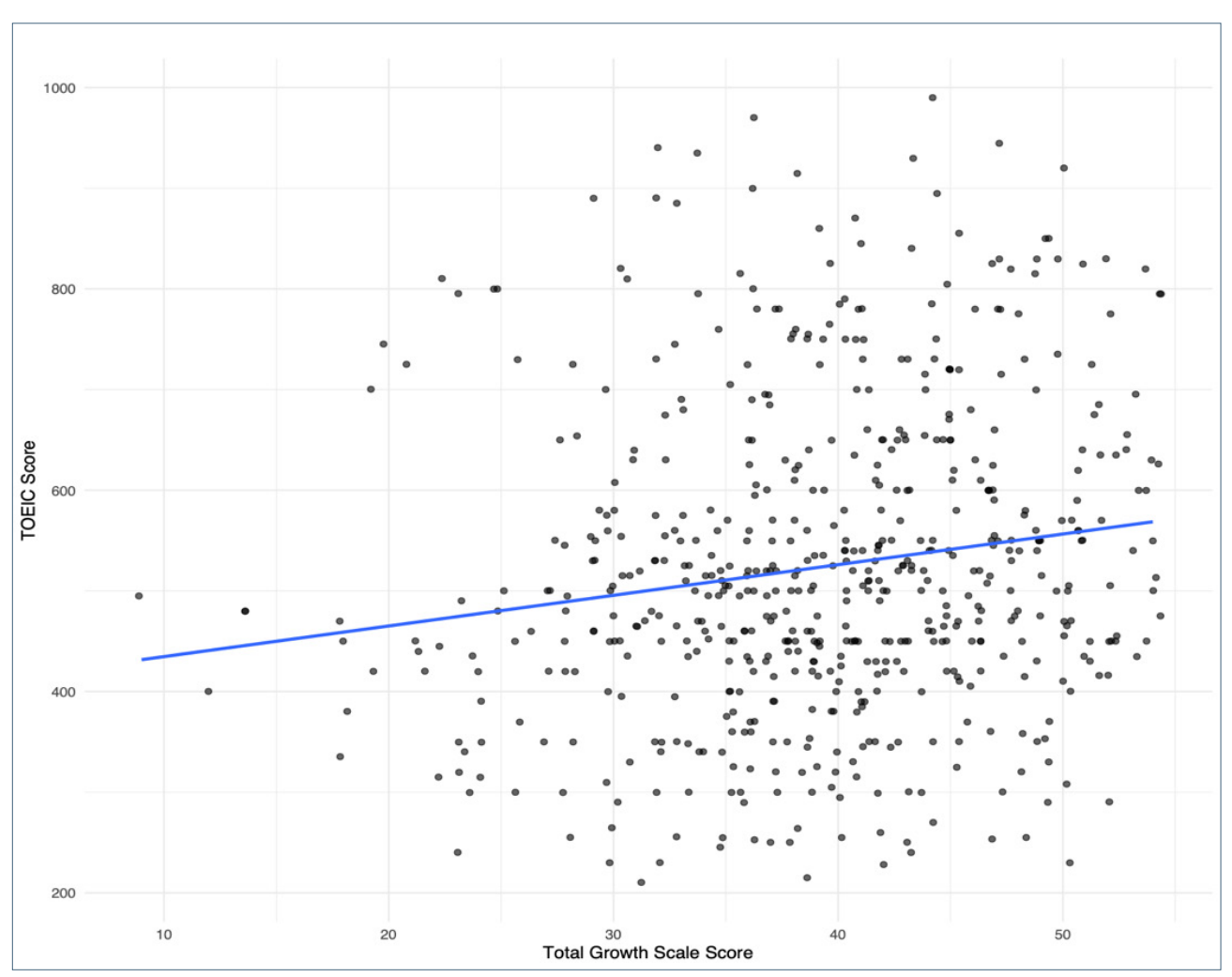

Figure 3. Scatterplot of TOEIC scores and J-LMI growth mindset scale scores, $\mathrm{N}=598$. 


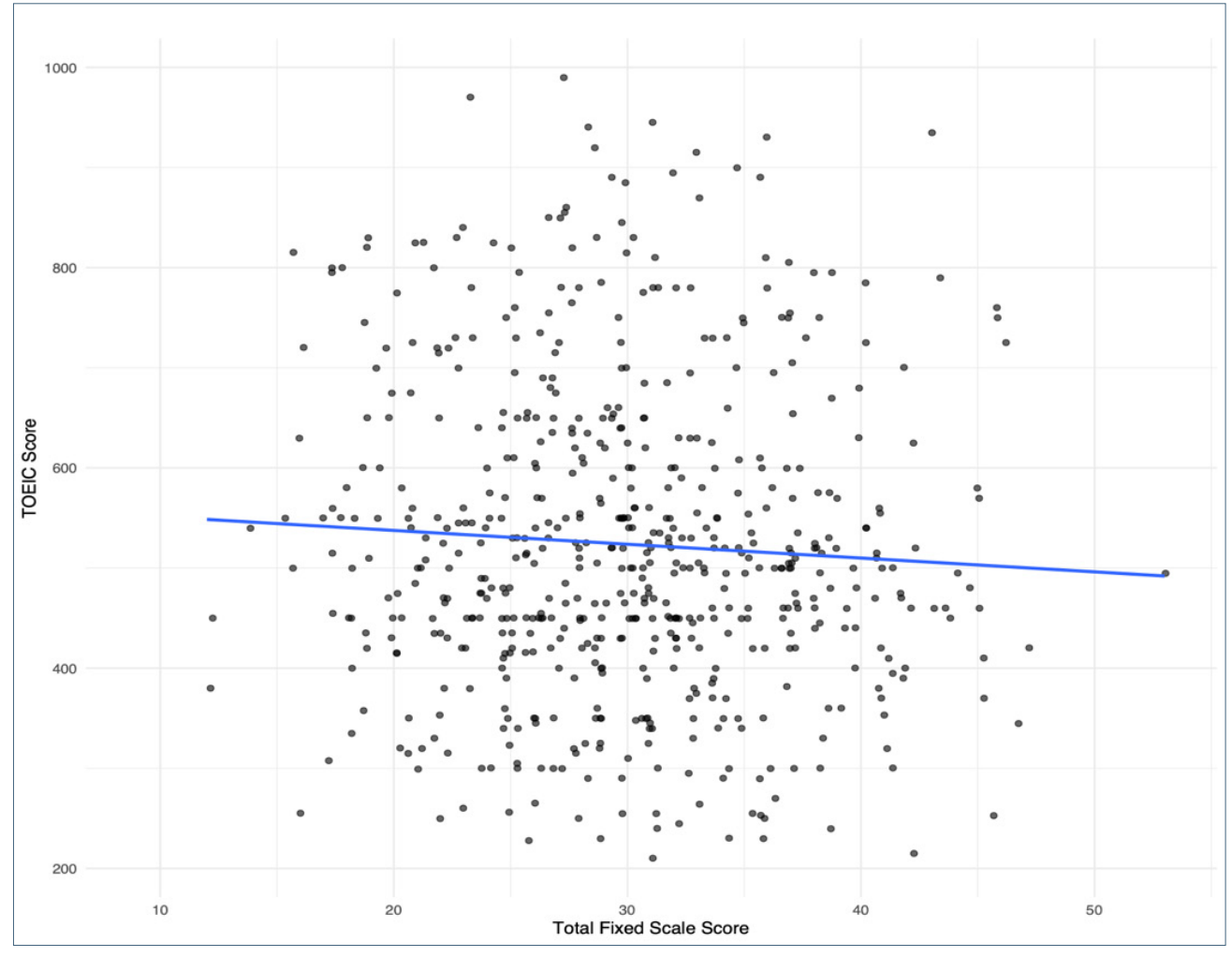

Figure 4. Scatterplot of TOEIC scores and J-LMI fixed mindset scale scores, $\mathrm{N}=598$.

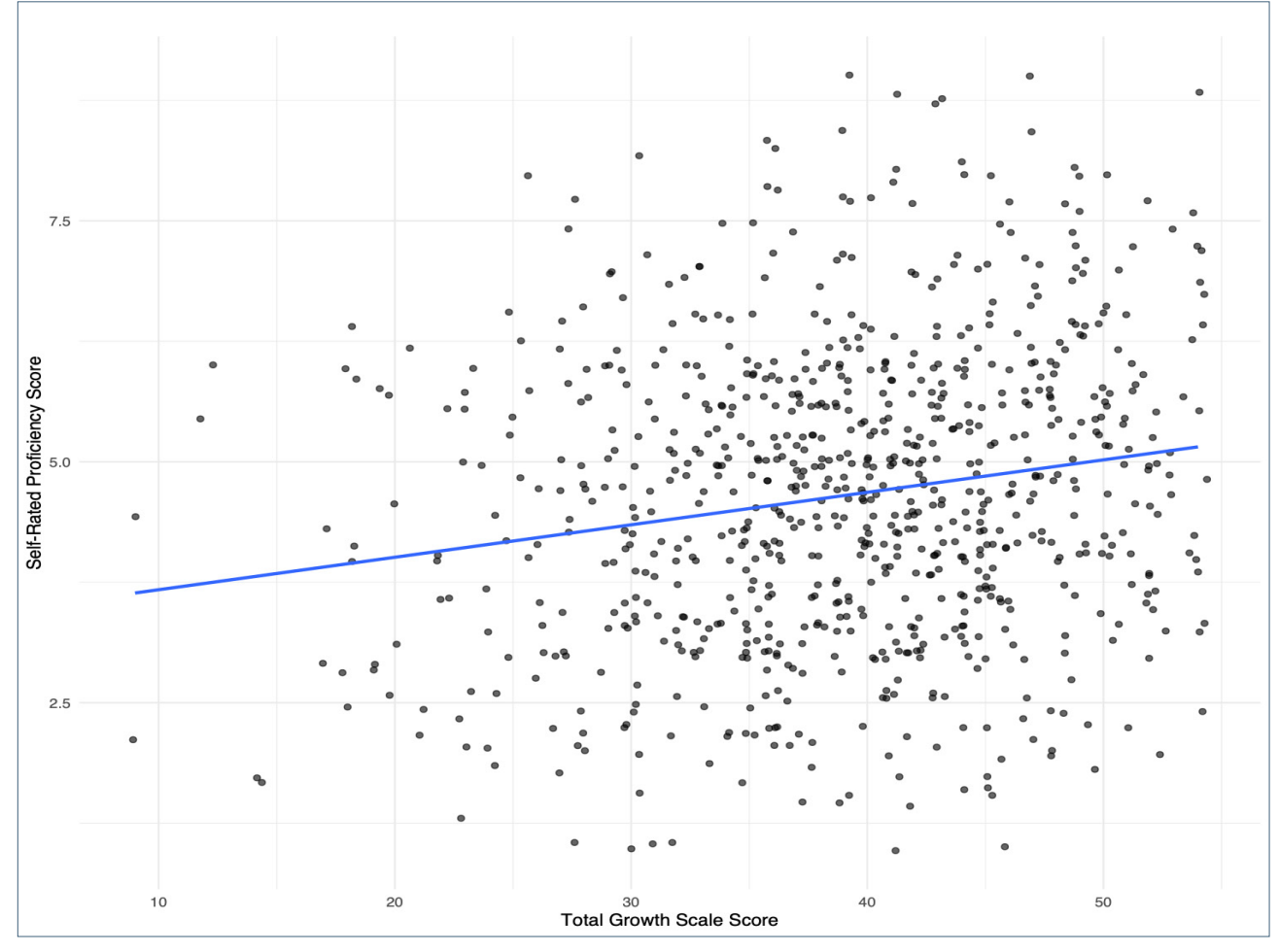

Figure 5. Scatterplot of self-rated proficiency scores and J-LMI growth mindset scale scores, $\mathrm{N}=825$. 


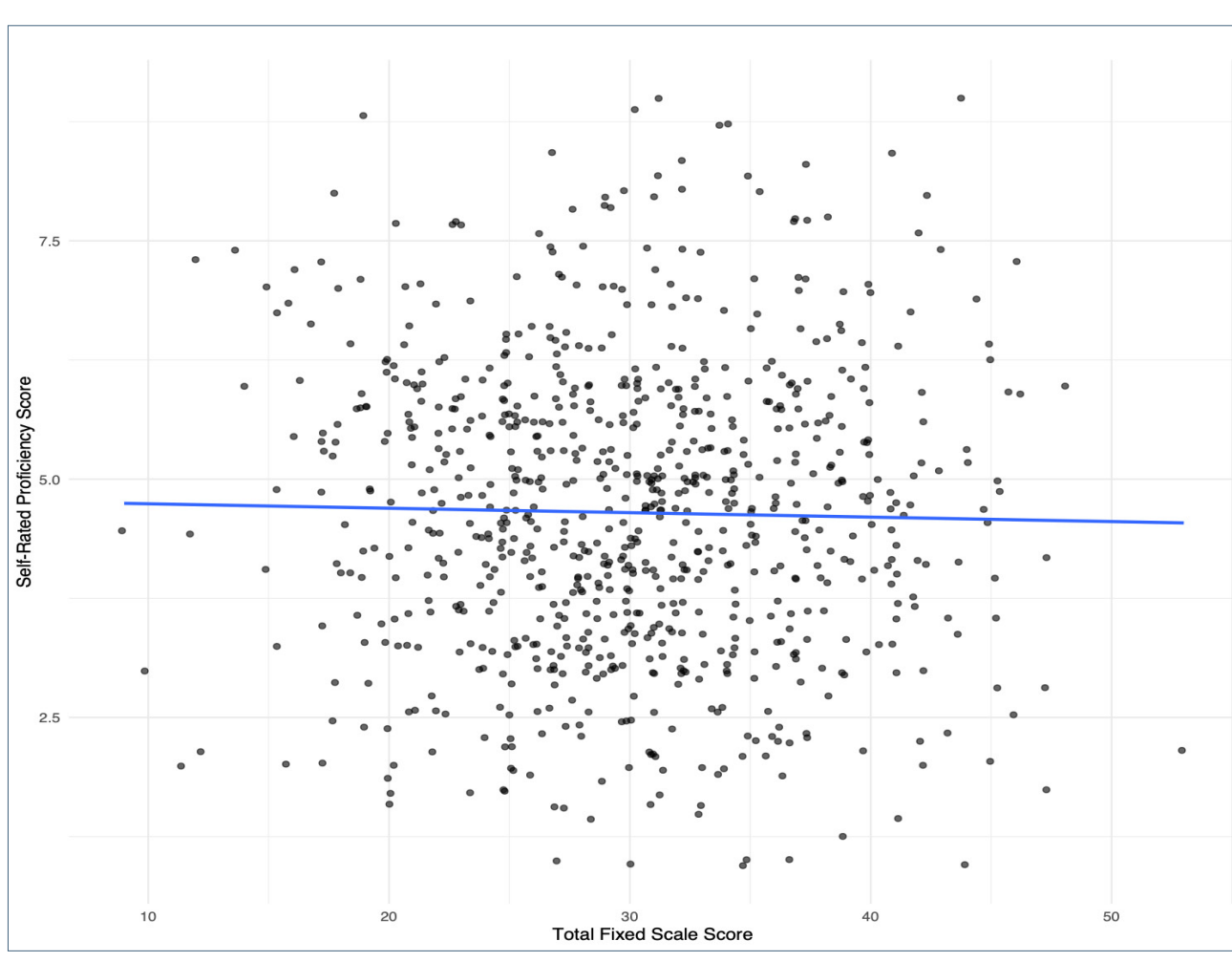

Figure 6. Scatterplot of self-rated proficiency scores and J-LMI fixed mindset scale scores, $\mathrm{N}=825$.

In labelling the two growth-scale factors (ML1 and ML4), we see phrases that differ the greatest in terms of the verbs used in the statements. The ML1 scale items use the following phrases "everyone can learn/can be fluent (dare demo ga shuutoku dekiru)" in tandem with conditional semantic chunks such as "if you work/if you work hard/if they tried hard (isshoukenmei ni benkyou sureba)." As well, phrases denoting achievement (learn/be a fluent speaker/improve/get better) or Japanese equivalents are present, suggesting a state of improvement or betterment. Achievement potential via hard work seems apt here as most of the scale items assert "If you apply effort, a better future state is possible."
Looking at the other growth-scale factor (ML4), notably every scale item contains some version of the phrase "can [...] change (kaeru koto wa dekiru)," a phrase absent in all ML1 items. There is a common thread of general or universal potential for things to change. Absent is the notion of work or effort, as is the notion of a unidirectional change for the better. Juxtaposing these two growth-scale factors (ML1 and ML4) we see surfacing a thematic difference characterized in the case of factor ML1 as an ability for an actor to impose their will via effort on current conditions and make them better, whereas thematically ML4 emphasizes the possibility of change but does not prioritize the role of the effort or efficacy of the learner's agency.

The two fixed-scale items (ML2 and ML3) appear more straightforward. The scale items contributing to ML3 all denote a certain forfeiture of learner agency. Thematically, all statements imply that biological factors determine outcomes along the lines of "you cannot really change," and "you're stuck with what you got." ML2, on the other hand, focuses almost entirely on a possible negative impact of age on the language learning process, suggesting that adulthood is too late to begin studying language, and the earlier one begins the better. One exception is L2Be2 ("it is difficult to change how good you are at foreign languages"), which, as can be seen in Tables 1 and 2, has somewhat problematic loadings across a number of factors.

One criticism that may be levelled here is that this discussion is focusing on the English version of the survey; readers might understandably wonder if this is apt considering the potential of semantic loss from the Japanese version. Our position here is that we have done all we can to maintain accuracy with translations and piloting, however further testing would be helpful here.

In terms of the regression results, they provide some support for the 2 -factor model and the validity of the scale, assuming that it is appropriate to make the assumption that higher ratings on the mindset scale will contribute to better test outcomes. Figure 3 shows that higher TOEIC-scoring students generally agreed more with the growth mindset statements; lower scoring students generally agreed less. As Figure 5 shows, this is also true with self-rated proficiency (SRP) scores. Regardless of TOEIC or SRP scores, there was a similar pattern of responses across the fixed mindset statements, as denoted in Figures 4 and 6.

One issue with these results is that the TOEIC and SRP scores were self-reported. This leads to the possibility of TOEIC scores being incorrectly reported or that the students did not correctly judge their SRP ratings. In regard to this latter point, it has been reported that anxiety can have a strong negative effect on learner's subjective perception of their language ability (Maclntyre \& Gregersen, 2012; Teimouri, Goetze, \& Plonsky, 
2018). As high levels of anxiety are associated with fixed language-learning mindsets (Lou \& Noels, 2019), it is likely that there may be some skewness in the data. The small effect sizes also need to be considered.

\section{Conclusion}

Based on the results of this study, it appears that the J-LMI supports a 2 -factor model in line with the original LMI. Although the 3- and 6-factor models do not hold in a Japanese EFL setting, we have identified a 4 -factor model that appears to identify different dimensions of language learning mindsets and have made an initial attempt to account for these factors. Further testing across different contexts would be useful to see to what extent these results are replicable.

One explanation for the disparity in findings could be because of the differences in methodology used in this study, namely our use of an inductive approach in the form of EFA as opposed to a deductive model-fitting CFA methodology. Another reason may relate to differences in the populations used in the two studies. In particular, the Japanese version of the survey was used with a homogenous language group studying English as a foreign language, with the majority of respondents enrolled in compulsory language classes, quite different to the ESL context used to validate the LMI. Finally, we cannot discount issues with the survey itself regarding its comprehensibility when translated into Japanese.

As far as we are aware, the LMI has yet to be tested or validated in other EFL contexts This study provides limited support for its validity and shows that it should be carefully tested in a variety of contexts prior to its wider implementation.

\section{Bio Data}

Paul Collett teaches at Shimonoseki City University, Yamaguchi Prefecture. His interests include teacher and learner psychology along with research methodology and epistemology.

Michael Berg is an instructor at a variety of universities mostly in Northern Kyushu. He is interested in educational psychology and linguistics and is currently completing his EdD at the University of Liverpool.

\section{References}

Aronson, J., Fried, C. B., \& Good, C. (2002). Reducing the effects of stereotype threat on African American college students by shaping theories of intelligence. Journal of Experimental Social Psychology, 38(2), 113-125. https://doi.org/10.1006/jesp.2001.1491

Blackwell, L. S., Trzesniewski, K. H., \& Dweck, C. S. (2007). Implicit theories of intelligence predict achievement across an adolescent transition: A longitudinal study and an intervention. Child Development, 78(1), 246-263. https://doi.org/10.1111/j.1467-8624.2007.00995.x

Brown, J. D. (2016). Statistics corner: Questions and answers about language testing statistics. Tokyo: JALT Testing and Evaluation Special Interest Group.

Dweck, C. S. (2000). Essays in social psychology. Self-theories: Their role in motivation, personality, and development. Philadelphia, PA: Psychology Press.

Dweck, C. S. (2006). Mindset: The new psychology of success. New York, NY: Random House

Dweck, C. S. (2008). Mindsets and math/science achievement. Retrieved from https://api.semanticscholar.org/CorpusID:38892105

Elliot, A. J., \& Dweck, C. S. (Eds.). (2013). Handbook of competence and motivation. New York, NY: Guilford Publications.

Field, A. P., Miles, J., \& Field, Z. (2012). Discovering statistics using R. London, England: Sage. Finch, W. H. (2019). Exploratory factor analysis. Thousand Oaks, CA: Sage.

Flora, D. B., \& Flake, J. K. (2017). The purpose and practice of exploratory and confirmatory factor analysis in psychological research: Decisions for scale development and validation. Canadian Journal of Behavioural Science / Revue canadienne des sciences du comportement, 49(2), 78-88. https://doi.org/10.1037/cbs0000069

Good, C., Aronson, J., \& Inzlicht, M. (2003). Improving adolescents' standardized test performance: An intervention to reduce the effects of stereotype threat. Journal of Applied Developmental Psychology, 24(6), 645-662. https://doi.org/10.1016/j.appdev.2003.09.002

$\mathrm{Hu}, \mathrm{L}$, \& Bentler, P. M. (1999). Cutoff criteria for fit indexes in covariance structure analysis: Conventional criteria versus new alternatives. Structural Equation Modeling, 6(1), 1-55. https://doi.org/10.1080/10705519909540118

Kaiser, H. F. (1974). An index of factorial simplicity. Psychometrika, 39(1), 31-36. https://doi.org/10.1007/BF02291575

Lou, N. M., \& Noels, K. A. (2016). Changing language mindsets: Implications for goal orientations and responses to failure in and outside the second language classroom. Contemporary Educational Psychology, 46, 22-33. https://doi.org/10.1016/j.cedpsych.2016.03.004

Lou, N. M., \& Noels, K. A. (2017). Measuring language mindsets and modeling their relations with goal orientations and emotional and behavioral responses in failure situations. The Modern Language Journal, 101(1), 214-243. https://doi.org/10.1111/modl.12380 
Lou, N. M., \& Noels, K. A. (2019). Promoting growth in foreign and second language education: A research agenda for mindsets in language learning and teaching. System, 86, 102126. https://doi.org/10.1016/j.system.2019.102126

MacIntyre P., \& Gregersen T. (2012). Affect: The role of language anxiety and other emotions in language learning. In S. Mercer, S. Ryan, \& M. Williams (Eds.), Psychology for language learning (pp. 103-118). Basingstoke, England: Palgrave Macmillan.

Meyers, M. C., van Woerkom, M., de Reuver, R. S., Bakk, Z., \& Oberski, D. L. (2015). Enhancing psychological capital and personal growth initiative: Working on strengths or deficiencies. Journal of Counseling Psychology, 62(1), 50-62. https://doi.org/10.1037/cou0000050

Preacher, K. J., \& MacCallum, R. C. (2003). Repairing Tom Swift's electric factor analysis machine. Understanding Statistics, 2(1), 13-43. https://doi.org/10.1207/S15328031US0201_02

Rattan, A., Good, C., \& Dweck, C. S. (2012). "It's ok-Not everyone can be good at math": Instructors with an entity theory comfort (and demotivate) students. Journal of Experimental Social Psychology, 48(3), 731-737. https://doi.org/10.1016/j.jesp.2011.12.012

Revelle, W. (2019). Psych: Procedures for psychological, psychometric, and personality research. R package version 1.9.12. Northwestern University, Evanston, IL. Available from https://CRAN.R-project.org/package=psych

Ryan, S., \& Mercer, S. (2011). Natural talent, natural acquisition and abroad: Learner attributions of agency in language learning. In G. Murray, X. Gao, \& T. Lamb (Eds.), Identity, motivation and autonomy in language learning (pp. 160-176). Clevedon, England: Multilingual Matters.

Ryan, S., \& Mercer, S. (2012). Implicit theories: Language learning mindsets. In S. Mercer, S. Ryan, \& M. Williams (Eds.), Psychology for language learning (pp. 74-89). Basingstoke, England: Palgrave Macmillan.

Schmidt, J. A., Shumow, L., \& Kackar-Cam, H. Z. (2017). Does mindset intervention predict students' daily experience in classrooms? A comparison of seventh and ninth graders trajectories. Journal of Youth and Adolescence, 46(3), 582-602.

https://doi.org/10.1007/s10964-016-0489-z

Spenner, M. (2017). Growth mindset: Trend or real science? Journal of Initial Teacher Inquiry, 3, 5356. Retrieved from http://hdl.handle.net/10092/14639

Teimouri, Y., Goetze, J., \& Plonsky, L. (2019). Second language anxiety and achievement: A metaanalysis. Studies in Second Language Acquisition, 41(2), 363-387. https://doi.org/10.1017/S0272263118000311

Yeager, D. S., Romero, C., Paunesku, D., Hulleman, C. S., Schneider, B., Hinojosa, C., . . . Dweck, C. S. (2016). Using design thinking to improve psychological interventions: The case of the growth mindset during the transition to high school. Journal of Educational Psychology, 108(3), 374-391. https://doi.org/10.1037/edu0000098

\section{Appendix}

LMI and J-LMI Scale Items

\begin{tabular}{llll}
\hline LMI & J-LMI & Mindset & Scale Item \\
\hline Age & ML1 & GROWTH & $\begin{array}{l}\text { Everyone could do well in foreign languages if } \\
\text { they tried hard, whether young or old } \\
\end{array}$ \\
ASBi1 & & $\begin{array}{l}\text { 年齢にかかわらず、努力する事で誰でも外国語が習得 } \\
\text { 出来ると思う }\end{array}$
\end{tabular}

Age

ASBi2

Age

ML1

ASBi3

L 2 beliefs

ML1

L2Bi1

L 2 beliefs

ML1

$\mathrm{L} 2 \mathrm{Bi} 2$

Age

ML2

ASBe1

Age

ML2

$\mathrm{ASBe} 2$
GROWTH Regardless of the age at which they start, people can learn another language well 何歳から始めても、人は他の言語を学ぶことができる

GROWTH How well a person learns a foreign language does not depend on age; anyone who works hard can be a fluent speaker in that language ごれだけよく外国語を学べるかに年齢は関係ないと思 う。一生懸命に勉強すれば、その言語を流ちょうに話 せるようになる

GROWTH How good you are at using a foreign language will always improve if you work at it

外国語の運用能力は、それに対して取り組みをすれば 常に向上すると思う

GROWTH In learning a foreign language, if you work hard at it, you will always get better

外国語を学ぶにあたつて、一生懸命に勉強すれば上 達すると思う

FIXED People can't really learn a new language after they reach adulthood

大人になってから新しい言語を学ぶ事は難しいと思う

Even if you try, the skill level you achieve in a foreign language will advance very little if you learn it when you're an adult

大人になってから外国語を学ぶと試みても、あまり上 達しないと思う 


\begin{tabular}{|c|c|c|c|}
\hline LMI & J-LMI & Mindset & Scale Item \\
\hline Age & $\begin{array}{l}\text { ML2 } \\
\text { ASBe3 }\end{array}$ & FIXED & $\begin{array}{l}\text { How well a person speaks a foreign language } \\
\text { depends on how early in life they learned it } \\
\text { どれだけ外国語を上手く話せるかは、どれだけ早い段 } \\
\text { 階で学習したかによって決まると思う }\end{array}$ \\
\hline L 2 beliefs & $\begin{array}{l}\text { ML2 } \\
\text { L2Be2 }\end{array}$ & FIXED & $\begin{array}{l}\text { It is difficult to change how good you are at } \\
\text { foreign languages } \\
\text { 外国語を上手く使えるようになることは難しいと思う }\end{array}$ \\
\hline L 2 beliefs & $\begin{array}{l}\text { ML3 } \\
\text { L2Be1 }\end{array}$ & FIXED & $\begin{array}{l}\text { To a large extent, a person’s biological factors (ie: } \\
\text { brain structures) determine his/her abilities to } \\
\text { learn new languages } \\
\text { たいていの場合、その人の生物学的要因(すなわち、 } \\
\text { 脳の構造)が新しい言語を学ぶ能力を決めると思う }\end{array}$ \\
\hline L 2 beliefs & $\begin{array}{l}\text { ML3 } \\
\text { L2Be3 }\end{array}$ & FIXED & $\begin{array}{l}\text { Many people can never do well in foreign } \\
\text { language even if they try hard because they lack } \\
\text { natural language intelligence } \\
\text { 多くの人々は、母国語の言語インテリジェンスが久け } \\
\text { ているので、どれだけ頑張っても絶対に外国語を上手 } \\
\text { く使えない }\end{array}$ \\
\hline $\begin{array}{l}\text { Lang. } \\
\text { intelligence }\end{array}$ & $\begin{array}{l}\text { ML3 } \\
\text { GLBe1 }\end{array}$ & FIXED & $\begin{array}{l}\text { You have a certain amount of language } \\
\text { intelligence and you can't really do much to } \\
\text { change it } \\
\text { 人はある一定の「言語インテリジェンス」を持つており、 } \\
\text { 自分でそれを変えることはできない }\end{array}$ \\
\hline $\begin{array}{l}\text { Lang. } \\
\text { intelligence }\end{array}$ & $\begin{array}{l}\text { ML3 } \\
\text { GLBe2 }\end{array}$ & FIXED & $\begin{array}{l}\text { Your language intelligence is something about } \\
\text { you that you can't really change much } \\
\text { 言語インテリジェンスは、自分で大幅に変えることがで } \\
\text { きないものである }\end{array}$ \\
\hline $\begin{array}{l}\text { Lang. } \\
\text { intelligence }\end{array}$ & $\begin{array}{l}\text { ML3 } \\
\text { GLBe3 }\end{array}$ & FIXED & $\begin{array}{l}\text { To be honest, you can't really change your } \\
\text { language intelligence } \\
\text { 本音を言えば、言語インテリジェンスを本当に変えるこ } \\
\text { とはできないと思う }\end{array}$ \\
\hline
\end{tabular}

\begin{tabular}{|c|c|c|c|}
\hline LMI & J-LMI & Mindset & Scale Item \\
\hline L 2 beliefs & $\begin{array}{l}\text { ML4 - } \\
\text { L2Bi2 }\end{array}$ & GROWTH & $\begin{array}{l}\text { You can always change your foreign language } \\
\text { ability } \\
\text { 外国語能力はいつでも変える事ができる }\end{array}$ \\
\hline $\begin{array}{l}\text { Lang. } \\
\text { intelligence }\end{array}$ & $\begin{array}{l}\text { ML4 } \\
\text { GLBi1 }\end{array}$ & GROWTH & $\begin{array}{l}\text { You can always substantially change your } \\
\text { language intelligence } \\
\text { いつでも自分の言語インテリジェンスを大きく変えるこ } \\
\text { とができる }\end{array}$ \\
\hline $\begin{array}{l}\text { Lang. } \\
\text { intelligence }\end{array}$ & $\begin{array}{l}\text { ML4 } \\
\text { GLBi2 }\end{array}$ & GROWTH & $\begin{array}{l}\text { No matter how much language intelligence you } \\
\text { have, you can always change it quite a bit } \\
\text { 自分がどれほどの言語インテリジェンスを持っていたと } \\
\text { しても、いつでもそれかなり変えることができる }\end{array}$ \\
\hline $\begin{array}{l}\text { Lang. } \\
\text { intelligence }\end{array}$ & $\begin{array}{l}\text { ML4 } \\
\text { GLBi3 }\end{array}$ & Growth & $\begin{array}{l}\text { No matter who you are you can significantly } \\
\text { change your language intelligence level } \\
\text { 誰でも、言語インテリジェンスレベルを大き変えるこ } \\
\text { とができる }\end{array}$ \\
\hline
\end{tabular}

